UDC $159.923+351.74$

DOI: $10.26565 / 2410-1249-2020-14-05$

\title{
STUDY OF INDICATORS OF NERVOUS-PSYCHOLOGICAL RESISTANCE AND SOCIAL MATURITY IN MILITARY SERVANTS DURING THE MESSAGE OF PSYCHO
}

\author{
DViktor I. Mozgovyi \\ PhD, Associate Professor of Psychology \\ Kyiv National University of Trade and Economics \\ (+038) 067-507-0037 \\ e-mail: viktorbrain65@gmail.com \\ https://orcid.org/0000-0002-6157-5460
}

\begin{abstract}
The article is devoted to theoretical and empirical research, important personal characteristics of servicemen: neuropsychological stability and socio-psychological maturity, which are the focus of psychological influence by the psychologist of the military unit at all major stages of military activity from conscription to discharge. The article empirically examines the system of relationships between indicators of neuropsychological stability, sociopsychological maturity and social relations in military servicemen at the stages of adaptation and performance of tasks. A correlation analysis was performed, according to Pearson, with indicators of neuropsychological stability, social maturity and the quality of relationships with the immediate social environment. As a result of the analysis of the obtained data, it was found that social maturity is directly related to the quality of social relations in a serviceman, both in the family and in the military, and tends to increase during military service. The level of stability of neuropsychological stability associated with the growth of social maturity due to the reflex component. The servicemen performing the assigned tasks have a positive dynamics of increasing the level of social maturity due to the reflexive and moral component, which indicates their personal and professional growth due to organized psychological support. The tasks and the expected result of psychological support at the stages of adaptation and performance of tasks as assigned are determined. The main vectors of psychological influence on the part of a military psychologist are indicated. to increase the level of neuropsychological stability and socio-psychological maturity in the military.
\end{abstract}

Keywords: psychological support, stages of military activity, serviceman, psychological support, neuropsychological stability, social and psychological maturity.

\section{Problem statement in general and its connection with important scientific and practical}

tasks. One of the main tasks of the modern army is not only high-quality professional training of servicemen to perform the assigned tasks, but first of all, the formation of a socially mature and resistant to combat stress personality. This is especially true for young people, who are called up for military service and in the long run, for the most part, become a powerful reserve for the formation of a contract army. The solution of this problem is possible under the conditions of the organization of system psychological support of servicemen at all stages of military activity. At the same time, within the framework of organized psychological support, it provides a clear algorithm of practical measures by a military psychologist, who by his organized actions, at the stage of psychological influence, "triggers" a mechanism of changes in the serviceman's personality structure. neuropsychological stability.

Today, military psychologists widely describe measures of psychological support at certain stages of military activity, but they are not integrated into a single system of psychological support, and the main measures are aimed at psychological preparation for the assigned tasks and recovery and rehabilitation after their implementation.

The issue of determining and researching the main personal components, which, in our opinion, play a crucial role in the quality of not only the tasks assigned to them, but also in general the successful completion of military service during the term set by the state for conscripts is relevant.

Analysis of recent research and publications. In the general sense, the concept of "maturity" as one of the periods of personality ontogenesis is revealed in the works of GS Abramova, BS Bratus, EP Krupnik, L. Orban-Lembrik, RF Pasichnyak, and 
others, and is characterized tendency to achieve the highest level of development of all human abilities. (Chebykin, 2009)

Certain psychological criteria of personality maturity, such as functional autonomy, realism, ability to distinguish between ideal and real goals, high level of reflection, self-control and flexibility of behavior, developed sense of responsibility, stable and consistent values, the need to search for meaning in life, tolerance for their own and others' shortcomings, the ability to actively participate in society and effectively use their knowledge and potential for psychological intimacy with another person, to constructively solve various life problems were the focus of research by scientists such as K.O. Abulkhanova-Slavska, L.I. Bozhovych, M.J. Boryshevsky, L.F. Burlachuk, G.S. Kostyuzh, I.S. Kon, A.G. Maslow, K. Obukhovsky, L.V. Potapchuk, V.O. Yadovy and etc. (Chebykin, and Pavlova, 2009)

The analysis of research on the study of social maturity among the military is characterized by a wide range of subject bases.

O. M. Pustovy, studying the socio-psychological factors of interaction of servicemen, considered social maturity as one of the levels of development of the team. (Empty, 2017)

S. S. Yegunov and T. A. Macedonia, analyzing the personal qualities of young people - students and servicemen, identified the criteria of psychological maturity: meaning-making and value orientations, the level of subjective control, coping strategies, as well as self-esteem. (Egunova, and Makedon, 2020)

E. N. Priymak, studying the peculiarities of the formation of social maturity of conscripts in the process of socialization during military service, made the following conclusion: service in the army, as a turning point in the life of a conscript, changing the social situation of development, provokes personal crisis, intensifies existential processes. and is reflected in the transformation of the life perspective of the individual. (Reception, 2014)

T. V. Makeeva, after analyzing the problem of socio-pedagogical support of social maturity of servicemen, defined social maturity as the end result of the socialization process, the result of which is a conscious social choice of the individual in the context of relationships with the surrounding social environment. In this regard, the social maturity of the soldier's personality lies in his ability to realize the need to build effective military-social relations. (Makeeva, 2020)

The problem of personal maturity in young men and women studying in civilian and military universities, also dealt with AV Miklyaev, IS Kletsin, in their work, the authors identified external (social) and internal (psychological) indicators of infantilization of personality and personal maturity. (Miklyaeva, and Kletsina, 2018)

O. S. Khacharyan, N. V. Barinova and A. O. Kharchenko determined the specificity of the structure of infantile traumatic experience in demobilized combatants with post-stress psychological maladaptation who have experienced different types of infantile trauma. (Kocharian, Barinova, and Kharchenko, 2018).

A. A. Kharchenko studied the issue of effective means of psychological influence on the military personality, in his work he developed a set of proposals for psychocorrection and diagnosis of traumatic emotional experience of servicemen in Ukraine with post-stress psychological maladaptation. (Kharchenko, 2020).

The problem of professional identity of the military and the study of the peculiarities of communication and motivation for service, we have shown

When studying the personal semantic sphere of servicemen and professional identity, we once noted that the motivation for service is semantic ideas about service in general, even in civilian life. (Mozghovyi, 2017)

A. A. Ozeryansky, studying the peculiarities of the development and course of maladaptation syndrome in servicemen of national units of the Armed Forces of Ukraine found that the main factor causing the development of maladaptation is mental stress, the manifestations of which are realized by increasing situational anxiety in $16.3 \%$ of peacekeepers; a decrease in the level of high psychoemotional stability in $33 \%$, a decrease in the level of NPS and the probability of psychological disruptions in $22.4 \%$, an increase in high levels: physical aggression to $49 \%$, indirect aggression to $19.1 \%$, 
verbal aggression to $71.3 \%$, irritation up to $34 \%$. One of the most informative methods for dynamic monitoring and early detection of maladaptation syndrome in servicemen of national units were psychological methods, including research: levels of neuropsychological stability - the method of "Forecast". (Ozeryansky, 2013)

Summarizing the analysis of the scientific literature devoted to the study of personal social maturity and neuropsychological stability in military servicemen, it should be noted that these important personal components were not the focus of subject research in organized psychological support at important stages of military growth.

Highlighting previously unsolved parts of the general problem to which this article is devoted. Today, military psychologists widely describe measures of psychological support at certain stages of military activity, but they are not integrated into a single system of psychological support and therefore the issue of developing and implementing a systematic approach to addressing the issue of quality psychological support for servicemen at each stage of military activity.

However, the lack of a properly developed unified methodological framework, incompletely defined functional content and the general concept of psychological support of servicemen do not allow to apply the practice of psychological support in military units at all stages of military activities and to have a positive impact on military psychologists for the military. effective performance of their professional duties and tasks.

Summarizing the analysis of the scientific literature devoted to the study of personal social maturity and neuropsychological stability in military servicemen, it should be noted that these important personal components were not the focus of subject research in organized psychological support at important stages of military growth.

The purpose of the article. The main purpose of our scientific research is to study such important personal characteristics of servicemen as neuropsychological stability and social maturity, during an organized set of psychological support activities at the stages of adaptation and performance of tasks.

\section{Objectives of the study:}

1. Investigate the system of relationships between indicators of neuropsychological stability, socio-psychological maturity and social relations in military servicemen at the stages of adaptation and performance of tasks as assigned.

2. To compare the specifics of the structural organization of indicators of neuropsychological stability and socio-psychological maturity in military servicemen at the stage of adaptation and the stage of performing tasks on purpose.

3. Identify the main vectors of psychological influence by the psychologist of the military unit in overcoming the main stressors associated with military service at the stages of adaptation and performance of tasks as assigned, within psychological support, defining the main purpose, objectives and results.

Presentation of the main research material. As a result of scientific research, we explored the concept of psychological support and identified the main stages of military activity at which it should be carried out (Brain, 2017).

Thus, we have identified six main stages: 1) the stage of professional and psychological selection; 2) the stage of adaptation to military service; 3) the stage of training and combat training; 4) the stage of performing tasks as assigned; 5) the stage of psychological recovery after completing the assigned tasks; 6) The stage of preparation for dismissal before the end of the term of service or contract. Seventh stage - work with the families of servicemen is carried out through all the above stages of military activity.

The focus of our study was two stages of military activity, the stage of adaptation and the stage of assignment, which in our opinion, can clearly represent the dynamics of socio-psychological growth and the formation of personal psychological stability in conscripts.

Based on the provisions of the theory of social construction of reality, a person learns cultural patterns (patterns) in the process of socialization throughout life. At the stage of secondary socialization, which falls on the age of conscription into the army (18-26 years), the formation of the worldview of the individual, enriches his ideas about 
personal purpose and meaning of life, learns the experience and traditions of generations. The events that a person experiences at this age and the experience that he receives - become values for his future life. (Schneider, 2007)

The formation of these guidelines is possible through the application of the algorithm developed by us sequential measures (stages) of psychological support at each of the above stages of military activity, which allows to carry out

complex impact on the personality and psyche of servicemen on the cognitive, emotional, behavioral and spiritual levels. The result is, in particular, facilitated adaptation of young recruits to the statutory requirements and the corresponding formation of a common military-professional identity and socio-psychological maturity. The consequence of this is the personal and militaryprofessional growth of young servicemen, which further affects the formation of their psychological stability and, accordingly, the quality and effective performance of their assigned tasks.

The study was conducted on the basis of $8 \mathrm{NC}$ (Training Center) of the State Special Transport Service (hereinafter - DSST). The study surveyed 279 servicemen, including 144 people at the stage of adaptation and 135 of the same conscripts at the stage of performing assigned tasks.

Determination of the level of neuropsychological stability was performed by the method of "Forecast". Indicators of social maturity were obtained using the self-assessment scale of personal maturity AV Miklyaeva.

According to the scale of self-assessment of personal maturity AV Miklyaeva, the following indicators of self-assessment of personal maturity are determined: self-assessment of cognitive maturity, reflexive maturity, regulatory maturity and moral maturity.

The study also used the Subjective SelfAssessment Questionnaire, developed by psychologists of the 8th NC DSST. The presence of a young person in the military team gives rise to special interpersonal relationships, which lead to the necessary "positive transfer" and, accordingly, successful identification with the image of the military and military service in general. Accordingly, our questionnaire contained a study of the following indicators: the desire to serve in the DSST, the quality of social relations: in the family, with comrades, commanders, the degree of personal courage, a sense of adulthood, the degree of stress.

The analysis of the sample was performed according to Pearson's test. The obtained data have a corresponding coefficient of statistical significance at the level of 0.01 , which indicates the presence of a significant difference between the obtained results.

The results of our correlation analysis are presented in the Table 1.

Table 1 presents Pearson's correlation analysis of indicators of social maturity, neuropsychological stability and assessment of social relationships in servicemen during their stage of adaptation to military service. The study involved 144 people.

As can be seen from Table 1 in conscripts, during their adaptation revealed:

1) that the quality of relationships in the family has a two-way relationship with the level of their reflexive maturity (0.002) and at the level of the trend with cognitive (0.012) and general maturity (0.023). Thus, we can assume that reflexive maturity, as the ability to adequately assess themselves, their actions and their consequences is formed under a positive microclimate in the family, the presence of harmonious relationships with parents and close social environment and affects the formation of cognitive and general maturity.

2) the quality of relationships with peers, at the level of the trend is related to the quality of relationships with seniors (0.024) and reflexive maturity (0.041). This existing ability to adequately assess and feel oneself, one's actions and their consequences "helps" not only to build quality relationships with older people in civilian life, but also older people in the army.

Thus, the formed social ties in the past have a positive effect on the construction of such relations between servicemen and "new" authoritative "adults" as commanders (superiors) during their service in the army. This affects the formation of ethics of business communication and the accumulation of new personal life experience, which in the future servicemen can effectively use in solving current life issues. 
3) Reflexive maturity at the level of tendency is related to the level of neuropsychological stability. This suggests that the increase in stress resistance of the individual is influenced by his reflexive ability to adequately assess themselves, their actions and their consequences.

4) General social maturity is represented by a holistic structure in which all components: reflexive $(0.000)$, regulatory $(0.000)$, moral $(0.000)$ and cognitive maturity $(0.000)$ are interconnected and have a complex psychological impact on the development of the personality of servicemen.
5) Neuropsychological resilience has a significant two-way relationship with suicidal tendencies $(0,000)$ and propensity to emotional breakdown $(0,000)$, which indicates its structural organization interrelated with these components. At the level of the trend, the connection of neuropsychological stability with reflexive maturity (0.11) was also revealed, which is an important vector of the psychologist's work with servicemen to further strengthen their psychological stability through this component.

Table 1

Correlation analysis of servicemen at the stage of "Adaptation"

\begin{tabular}{|c|c|c|c|c|c|c|c|c|c|c|c|c|c|}
\hline $\begin{array}{r}\text { Indicators accordin } \\
\text { "Forecast", self-as } \\
\text { personal } \\
\text { Questionnaires o } \\
\text { este }\end{array}$ & $\begin{array}{l}\text { g to the method of } \\
\text { sessment scales of } \\
\text { maturity, } \\
\text { f subjective self- } \\
\text { eem }\end{array}$ & 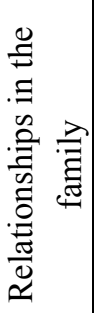 & 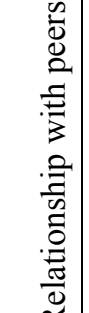 & 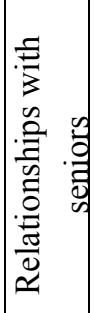 & 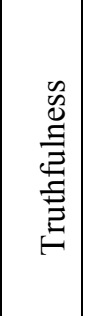 & 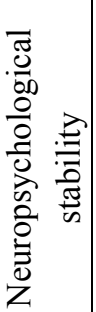 & 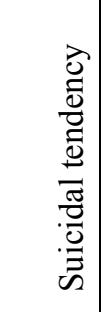 & 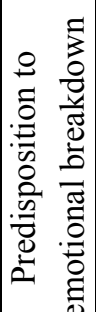 & 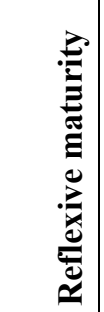 & 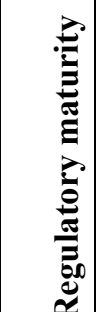 & 竧 & . & 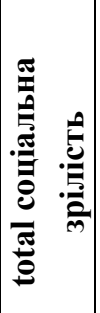 \\
\hline Relationships in & Pearson correlation & 1 & .113 & -.005 & .198 & -.165 & -.180 & -.034 & $.439^{* *}$ & .197 & .136 & $.371^{*}$ & $.335^{*}$ \\
\hline family & Value (bilateral) & & .457 & .975 & .187 & .274 & .232 & .822 & .002 & .190 & .375 & .012 & .023 \\
\hline Relationship with & Pearson correlation & .113 & 1 & $.336^{*}$ & .262 & -.086 & .044 & -.146 &. $\mathbf{3 0 3}^{*}$ & .238 & .237 & .219 & .234 \\
\hline peers & \begin{tabular}{|l|} 
Value (bilateral) \\
\end{tabular} & .457 & & .024 & .079 & .571 & .772 & .334 & .041 & .111 & .117 & .148 & .117 \\
\hline Relationships with & Pearson correlation & -.005 & $336^{*}$ & 1 & .134 & -.034 & .053 & .001 & .056 & .101 & .092 & $.368^{*}$ & .111 \\
\hline seniors & \begin{tabular}{|l|} 
Value (bilateral) \\
\end{tabular} & .975 & .024 & & .381 & .827 & .731 & .996 & .714 & .511 & .554 & .014 & .466 \\
\hline Truthfulness & Pearson correlation & .198 & .262 & .134 & 1 & -.091 & -.058 & -.195 & .123 & .066 & -.055 & -.019 & .023 \\
\hline & Value (bilateral) & .187 & .079 & .381 & & .549 & .700 & .194 & .414 & .664 & .719 & .899 & .880 \\
\hline Neuropsychological & Pearson correlation & -.165 & -.086 & -.034 & -.091 & 1 & $.874^{* *}$ & $.802^{* *}$ & $-.371^{*}$ & -.180 & -.240 & -.159 & -.231 \\
\hline stability & Value (bilateral) & .274 & .571 & .827 & .549 & & .000 & .000 & .011 & .230 & .113 & .296 & .123 \\
\hline Suicidal tendency & Pearson correlation & -.180 & .044 & .053 & -.058 & $.874^{* *}$ & 1 & $.777^{* *}$ & $-.418^{* *}$ & -.209 & -.147 & -.259 & -.260 \\
\hline & \begin{tabular}{|l|l} 
Value (bilateral) \\
\end{tabular} & .232 & .772 & .731 & .700 & .000 & & .000 & .004 & .163 & .335 & .086 & .081 \\
\hline Predisposition to & Pearson correlation & -.034 & -.146 & .001 & -.195 & $.802^{* *}$ & $.777^{* *}$ & 1 & -.241 & -.158 & -.235 & \begin{tabular}{|l|}
-.033 \\
\end{tabular} & -.171 \\
\hline $\begin{array}{l}\text { emotional } \\
\text { breakdown }\end{array}$ & Value (bilateral) & .822 & .334 & 996 & .194 & .000 & .000 & & 107 & .293 & .120 & .828 & .255 \\
\hline Reflexive maturity & Pearso & $.439^{* *}$ & $.303^{*}$ & .056 & 123 & $-.371^{*}$ & $-.418^{* *}$ & -.241 & 1 & $.697^{* *}$ & $.619^{* *}$ & $.629^{* * *}$ & $.782^{* *}$ \\
\hline & Value (bilateral) & .002 & .041 & .714 & .414 & .011 & .004 & .107 & & .000 & .000 & .000 & .000 \\
\hline Regulatory & Pearson correlation & .197 & .238 & .101 & .066 & -.180 & -.209 & -.158 & $.697^{* *}$ & 1 & $.513^{* *}$ & $.625^{* *}$ & $.722^{* *}$ \\
\hline maturity & Value (bilateral) & .190 & .111 & .511 & .664 & .230 & .163 & .293 & .000 & & .000 & .000 & .000 \\
\hline Moral maturity & Pearson correlation & .136 & .237 & .092 & -.055 & -.240 & -.147 & -.235 & $.619^{* *}$ & $.513^{* *}$ & 1 & $.407^{* *}$ & $.742^{* * *}$ \\
\hline & Value (bilateral) & .375 & .117 & .554 & .719 & .113 & .335 & .120 & .000 & .000 & & .005 & .000 \\
\hline Cognitive & Pearson correlation & $.371^{*}$ & .219 & $368^{*}$ & -.019 & -.159 & -.259 & -.033 & $.629^{* *}$ & $.625^{* *}$ & $.407^{* *}$ & 1 & $.820^{* * *}$ \\
\hline maturityb & Value (bilateral) & .012 & .148 & .014 & \begin{tabular}{|l|}
.899 \\
\end{tabular} & .296 & .086 & .828 & .000 & .000 & .005 & & .000 \\
\hline total соціальна & Pearson correlation & $.335^{*}$ & .234 & .111 & .023 & -.231 & -.260 & -.171 & $.782^{* *}$ & $.722^{* *}$ & $.742^{* *}$ & $.820^{* * *}$ & 1 \\
\hline зрілість & Value (bilateral) & .023 & .117 & .466 & .880 & .123 & .081 & .255 & .000 & .000 & .000 & .000 & \\
\hline
\end{tabular}


It was found that in the stage of adaptation, the neuropsychological stability and reflexive maturity of servicemen have "their" interrelated components, which can further positively affect the personality of servicemen.

Table 2 presents Pearson's correlation analysis of indicators of social maturity, neuropsychological stability and assessment of social relationships in conscripts who were involved in the guard service when performing assigned tasks. The study involved 135 servicemen.

Table 2

Correlation analysis of servicemen at the stage of "performing tasks as assigned "

\begin{tabular}{|c|c|c|c|c|c|c|c|c|c|c|c|c|c|}
\hline \multicolumn{2}{|c|}{$\begin{array}{c}\text { Indicators according to the method } \\
\text { of "Forecast", self-assessment scales } \\
\text { of personal maturity, } \\
\text { Questionnaires of subjective self- } \\
\text { esteem }\end{array}$} & 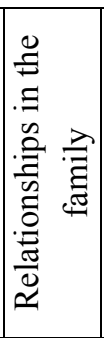 & 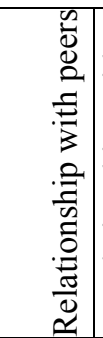 & 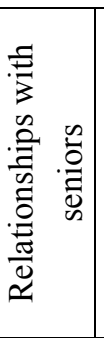 & 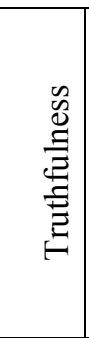 & 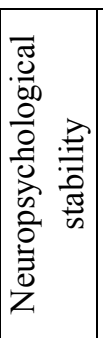 & 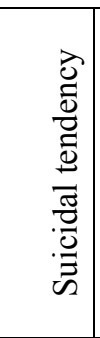 & 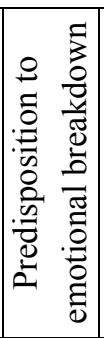 & 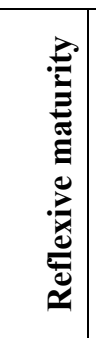 & 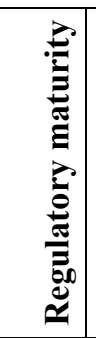 & 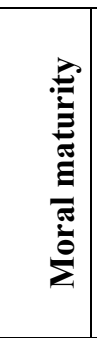 & 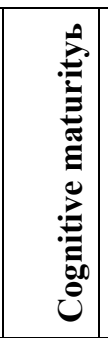 & 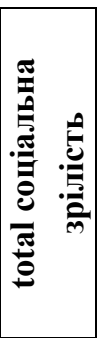 \\
\hline \multirow{2}{*}{$\begin{array}{l}\text { Relationships } \\
\text { in the family }\end{array}$} & & & $.568^{* *}$ & $.394^{*}$ & .171 & -.174 & $-.384^{*}$ & $-.356^{*}$ & $.624^{* * 3}$ & .333 & $.392^{*}$ & $.486^{* * *}$ & \\
\hline & $\mathrm{Val}$ & & .001 & .026 & .350 & .341 & .030 & .045 & .000 & .062 & .027 & .005 & \\
\hline \multirow{2}{*}{$\begin{array}{l}\text { Relationship } \\
\text { with peers }\end{array}$} & & $8^{* *}$ & & $.655^{* *}$ & .327 & -.218 & -.212 & -.192 & $.706^{* * *}$ & $.418^{*}$ & $.566^{* *}$ & $.368^{*}$ & \\
\hline & & .001 & & .000 & .059 & .216 & .228 & .278 & .000 & .014 & .000 & .032 & \\
\hline \multirow{2}{*}{$\begin{array}{l}\text { Relationships } \\
\text { with seniors }\end{array}$} & & $.394^{*}$ & $.655^{* *}$ & & $.345^{*}$ & -.193 & .040 & -.051 & $.426^{*}$ & $.348^{*}$ & $.516^{* *}$ & .249 & {$\left[\begin{array}{rl}0 . \\
\end{array}\right.$} \\
\hline & & .026 & .000 & & .046 & .275 & .821 & .776 & .012 & .044 & .002 & .156 & \\
\hline \multirow[t]{2}{*}{ ruthfulness } & & .171 & .327 & $.345^{*}$ & 1 & .102 & .181 & -.083 & $.399^{*}$ & .211 & $.400^{*}$ & $.404 *$ & .440 \\
\hline & & .350 & .059 & .046 & & .565 & .305 & .641 & & .232 & .019 & .018 & \\
\hline \multirow{2}{*}{$\begin{array}{l}\text { Neuropsychol } \\
\text { ogical stability }\end{array}$} & & 174 & -.218 & -.193 & .102 & 1 & $.624^{* *}$ & $.599^{* *}$ & -.197 & -.237 & -.320 &.- .337 & -.34 \\
\hline & & .341 & .216 & .275 & .565 & & .000 & .000 & .265 & .178 & .065 & .052 & \\
\hline \multirow{2}{*}{$\begin{array}{l}\text { Suicidal } \\
\text { endency }\end{array}$} & & $.384^{*}$ & -.212 & .040 & .181 & $.624^{* *}$ & & $.582^{* *}$ & -.220 & -.156 & -.031 & -.144 & \\
\hline & & .030 & .228 & .821 & .305 & .000 & & .000 & .211 & .379 & .863 & .416 & \\
\hline \multirow{2}{*}{$\begin{array}{l}\text { Predisposition } \\
\text { to emotional } \\
\text { breakdown }\end{array}$} & & & -.192 & -.051 & 883 & $.599^{* *}$ & $82^{* *}$ & & 144 & -.205 & .115 & -.137 & \\
\hline & & .045 & .278 & .776 & .641 & .000 & .000 & & .417 & .246 & .516 & .43 & \\
\hline \multirow{2}{*}{$\begin{array}{l}\text { Reflexive } \\
\text { maturity }\end{array}$} & & & $.706^{* *}$ & .426 & $399^{\prime}$ & -.197 & -.220 & -.144 & & & $.642^{* *}$ & $.467^{* *}$ & \\
\hline & & .000 & .000 & .012 & 019 & .265 & .211 & .417 & & .004 & .000 & .005 & \\
\hline \multirow{2}{*}{$\begin{array}{l}\text { Regulatory } \\
\text { naturity }\end{array}$} & & .333 & $.418^{*}$ & $.348^{*}$ & .211 & -.237 & -.156 & -.205 & $.481^{* * *}$ & 1 & $.554^{* *}$ & $.457^{* *}$ & .756 \\
\hline & & .062 & .014 & .044 & .232 & .178 & .379 & .246 & .004 & & .001 & .007 & \\
\hline \multirow{2}{*}{$\begin{array}{l}\text { Moral } \\
\text { naturity }\end{array}$} & & $.392^{*}$ & $.566^{* *}$ & $.516^{* *}$ & $.400^{*}$ & -.320 & -.031 & -.115 & $.642^{* * *}$ & $.554^{* *}$ & & $.637^{* * *}$ & .875 \\
\hline & & .027 & .000 & .002 & .019 & .065 & .863 & .516 & .000 & .001 & & .000 & \\
\hline \multirow{2}{*}{$\begin{array}{l}\text { Cognitive } \\
\text { naturityь }\end{array}$} & & $486^{* *}$ & $.368^{*}$ & .249 & $404^{*}$ & -.337 & -.144 & -.137 & $.467^{* * *}$ & $.457^{* *}$ & $.637^{* *}$ & & .825 \\
\hline & & .005 & .032 & .156 & .018 & .052 & .416 & .438 & .005 & .007 & .000 & & \begin{tabular}{|l|}
.0 \\
\end{tabular} \\
\hline \multirow{2}{*}{$\begin{array}{l}\text { total } \\
\text { соціальна } \\
\text { зрілість }\end{array}$} & & & $.619^{* *}$ & $.465^{* *}$ & $.440^{* *}$ & $-.344^{*}$ & -.166 & -.184 & & $.756^{* *}$ & $.875^{* *}$ & $.825^{* *}$ & \\
\hline & Value (bilateral) & & .000 & .00 & .009 & .046 & .34 & .298 & .00 & .000 & .00 & .00 & \\
\hline
\end{tabular}

** Correlation is significant at the 0.01 level (two-tailed)

* Correlation is significant at the 0.05 level (two-tailed)

As can be seen from Table 2, conscripts at the stage of performing their assigned tasks revealed the following:

1) The quality of family relations in servicemen has a statistically significant two-way relationship with servicemen (0.001), as well as with the level of

their reflexive (0.000), cognitive (0.000) and general social maturity (0.000). At the stage of adaptation of servicemen to military activity, such a connection was found at the level of trends.

The revealed positive dynamics in conscripts at the stage of performing their assigned tasks in 
comparison with the results obtained in servicemen at the stage of adaptation (Table 1) may indicate an increase in the general level of their social maturity, within psychological support during conscription, and accordingly also simultaneous increase of level of significance for them of relations in a family.

2) The quality of relationships with employees has a statistically significant two-way relationship with socially significant family relationships $(0.001)$, relationships with commanders $(0.000)$ and the level of reflexive (0.000), moral $(0.000)$ and general social maturity $(0.000)$.

At the stage of adaptation of servicemen to military activity, such a connection was found at the level of the trend only with the elderly (0.24) and reflexive maturity (0.041).

3) Relationships with commanders have a statistically significant two-way relationship with relations with employees $(0.000)$ and the level of moral (0.002) and general social maturity (0.005).

The statistically significant relationship between relations with employees and commanders with moral maturity (0.000) can be explained by the fact that commanders are entrusted with the functions of translation and control over compliance with socially approved, "new" norms of behavior by subordinates, which are due not only to statutory requirements but also personal example, which in turn stimulates the development of moral maturity in the military.

This may also indicate that the psychological support of servicemen, organized by the psychologist of the unit together with the department of moral and psychological support and command of the unit at all stages of military activity stimulates rapid social maturation. And, as a consequence, has a positive effect on the personality of conscripts in relation to their stay in the military, for example, to follow the "new" socially significant norms of behavior due to the statute, the peculiarities of military service, which leads to the general development of social maturity.

4) Sincerity at the stage of performing the assigned tasks has a statistically significant relationship with the general level of social maturity. We have not received such links during the adaptation phase.
This may indicate that military service stimulates personnel to form certain moral values and a more objective personal self-assessment of their behavior and the behavior of other employees (their peers), responsibility for the performance of their duties and, accordingly, the expected assessment of their comrades for them. implementation. Openness and trust are becoming the norm in communication and "new" relationships, due to the requirements of military service.

5) It was found that the level of neuropsychological stability in a serviceman has a statistically significant relationship with the tendency to suicidal behavior (0.000) and emotional breakdown (0.000). In addition, the level of neuropsychological stability is related to the level of the trend with the level of general social maturity (0.046).

6) General social maturity, at the stage of performing the tasks assigned to conscripts also retains its holistic structure, in which all components (reflexive, regulatory, moral and cognitive maturity) are interconnected, which confirms our assumption about its professionally important component in personal growth of servicemen while serving in the army.

Preservation of the structural organization of psychological stability and general social maturity and their positive dynamics at such important stages of military activity as adaptation and performance of assigned tasks indicates that both components are important for both personal and professional growth of servicemen. Thus, a higher level of general social maturity at the stage of performing tasks with the "inclusion" of the moral component, compared with the stage of adaptation, indicates the personal and professional growth of servicemen and their maintenance of stable psychological stability, which is necessary and sufficient for quality performance of tasks by them on purpose.

Approbation of the model of psychological support on the basis of $8 \mathrm{NC}$ DSST allowed to provide a continuous process of support, to determine the principles, content and its tasks at the main stages of military activity.

Below are the schemes of psychological support, which was used in the studied stages of "Adaptation" and "Performing tasks on purpose." 
Figure 1 shows the main content of the task defined by us and the result that should be obtained at the stage of adaptation. As you can see, the main task of this stage of military activity is the adaptation of personnel to the conditions and features of their military service. As a result, there must be a successful personal identification of conscripts with military service and its requirements, increasing the level of NPS and stress resistance, as well as psychological readiness to perform the assigned tasks.

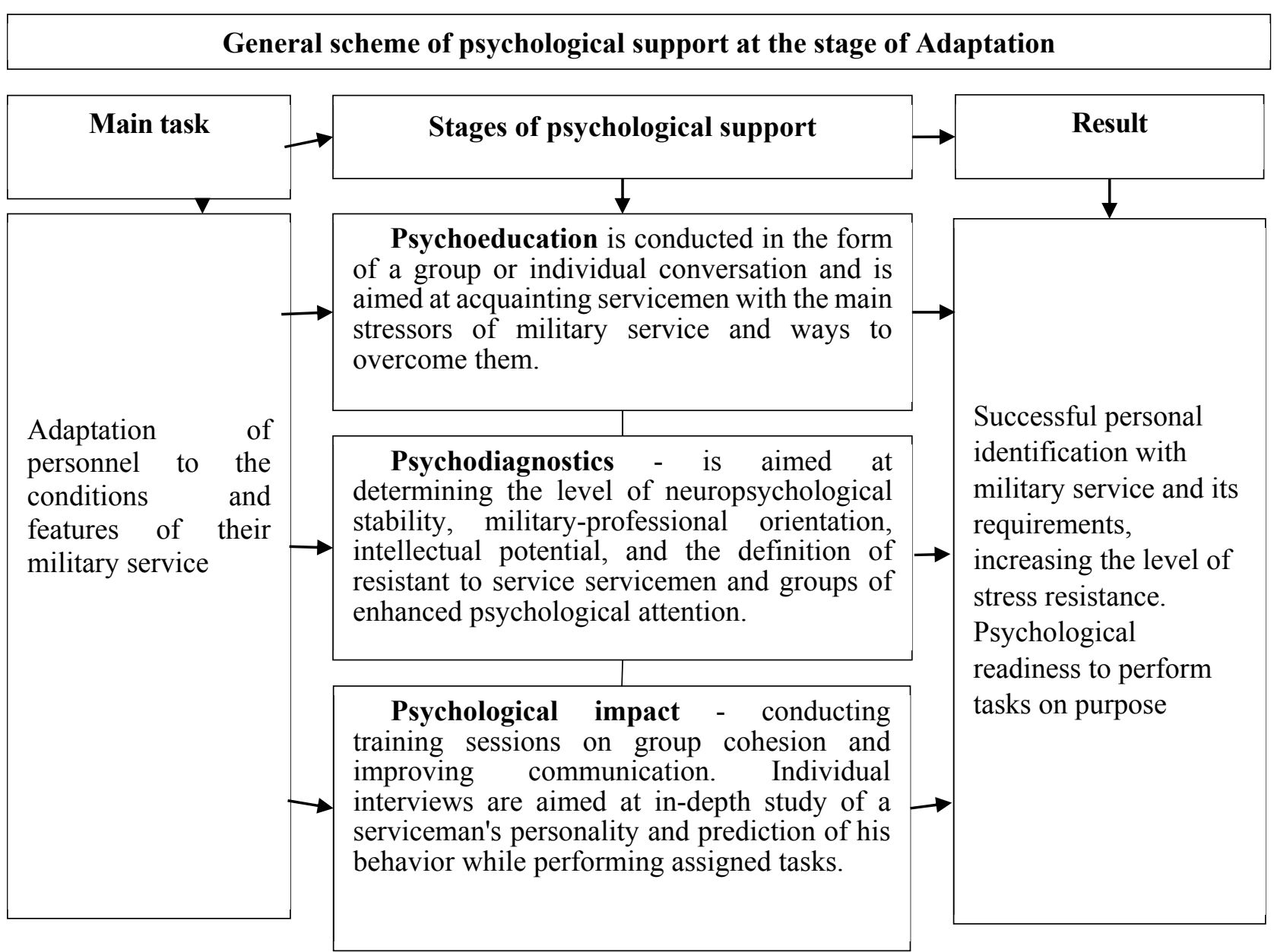

Figure 1. Scheme of psychological support at the stage of Adaptation

Figure 2 shows the main content of the task defined by us and the result that should be obtained at the stage of performing the tasks as intended. As you can see, the main task of this stage of military activity is to monitor the psychological state of personnel and measures to maintain the resource psychological state of servicemen.

As a result, support should be provided at the optimal level of psychological stability of servicemen and a positive psychological microclimate in the military team when performing assigned tasks.

The analysis of the results obtained during the study allowed us to reach the following conclusions:
1. It was found that the reflexive maturity developed in military service, in civilian life in relations in the family, with peers and older people has a positive effect on their adaptation to the requirements of military life and building "new" relationships with servicemen and commanders.

2. Reflexive maturity at the level of tendency is related to the level of neuropsychological stability. This indicates that the increase in further stress resistance of the individual is influenced by his reflexive ability to adequately assess themselves, their actions and their consequences.

3. Conscripts at the stage of performing their assigned tasks in comparison with the results 
obtained from servicemen at the stage of adaptation revealed a positive dynamics of growth of three components of social maturity (reflexive, cognitive and general) by simultaneously increasing the importance of family relationships.

4. Statistically significant, for military servicemen, connections between moral maturity and relations with servicemen and commanders, which is an important specific feature of sociopsychological personal growth of servicemen who are at the stage of performing assigned tasks.

5. Sincerity at the stage of performing assigned tasks has a statistically significant relationship with the general level of social maturity, which may indicate the formation of such moral values as openness and trust, due to the nature of service in performing their duties and become the norm in communication and conditions vital activity.

6. Neuropsychological stability and social maturity at the stages of adaptation and performance of tasks on purpose reveal their holistic structure and have a positive dynamics of personal development within the organized psychological support of servicemen due to the moral component of social maturity, which positively affects personal and professional growth. services during the performance of their official duties.

7. Ensuring a continuous process of psychological support at all stages of military service, including adaptation and performance of assigned tasks allows to determine the principles of specific content, tasks and expected results, which is the "road map" of the psychologist in military units.

\section{General scheme of psychological support at the stage of \\ Performing the task as intended}

\begin{tabular}{|c|c|c|}
\hline Main task & Stages of psychological support & Result \\
\hline$\downarrow$ & $\downarrow$ & $\downarrow$ \\
\hline \multirow{3}{*}{$\begin{array}{l}\text { Monitoring of } \\
\text { psychological states } \\
\text { of personnel. } \\
\text { Measures to support } \\
\text { the resource } \\
\text { psychological state }\end{array}$} & $\begin{array}{l}\text { Psychoeducation is conducted in order to } \\
\text { inform servicemen about the stressors that } \\
\text { await them during the assigned task and ways } \\
\text { to overcome them effectively. }\end{array}$ & \multirow{3}{*}{$\begin{array}{l}\text { Support at the optimal } \\
\text { level of psychological } \\
\text { stability of servicemen } \\
\text { and psychological } \\
\text { microclimate in the } \\
\text { military team }\end{array}$} \\
\hline & $\begin{array}{l}\text { Psychodiagnostics }- \text { is aimed at } \\
\text { determining the level of neuropsychological } \\
\text { stability, suicidal tendencies and emotional } \\
\text { breakdown, general personal stress resistance. }\end{array}$ & \\
\hline & \begin{tabular}{l}
\multicolumn{2}{c}{ Психологічний вплив - навчання } \\
навичкам психосаморегуляції \\
підвищення стресостійкості. Проведення \\
індивідуальних бесід спрямованих на \\
виявлення військовослужбовців вразливих \\
до впливу стрес-факторів , обумовлених \\
місцем несення служби.
\end{tabular} & \\
\hline
\end{tabular}

Figure 2. The scheme of psychological support at the stage of performing tasks on purpose

\section{References}

Chebykin, O. Ya.,, Pavlova, I. Н. (2009). Становлення емоиійної зрілості особистості [Formation of emotional maturity of the individual], (in Ukrainian)

Pustovyi, O. М. (2017). Соціально-психологічні чинники групової взаємодії військослужбовців: теоретична модель [Socio-psychological factors of group interaction of servicemen: theoretical model]. Aktualni problemy psykholohii, 1, 108-111, (in Ukrainian).

Egunova, S. S., Makedon, Т. А. (2020). Анализ личностных качеств юношей-студентов и военнослужащих [Analysis of the personal qualities of male students and military personnel]. Postulat, 11, (in Russian). 
Prijmak, E. N. (2014). Особенности становления социальной зрелости военнослужащих по призыву в процессе социализации на электронной почте службы в армии [Features of the formation of the social maturity of military personnel on a prize in the process of socialization at its stage of service in the army]. Rossijskij psikhologicheskij zhurnal, 11(2). (in Russian)

Makeeva, T. V. (2020). Социально-педагогическое сопровождение социальной зрелости военнослужащих [Social and pedagogical support of the social maturity of military personnel.]. Vestnik YaVVU PVO. 1, 147-154. (in Russian)

Miklyaeva, A. V., Kleczina, I. S. (2018). Личная зрелость и инфантилизм у юношей и девушек, обучающихся в гражданских и военных вузах: гендерный аспект [Personal maturity and infantilism in boys and girls studying in civil and military universities: a gender aspect]. Известия Российского государственного педагогического университета им. А. И. Гериена, 187. (in Russian)

Kocharian, O. S., Barinova, N. V., \& Kharchenko, A. O. (2018). Особливості структури інфантильного травматичного досвіду у демобілізованих учасників бойових дій в Україні з постстресовою психологічною дезадаптацією [Features of the structure of infantile traumatic experience in demobilized combatants in Ukraine with post-stress psychological maladaptation]. Psychological Counseling and Psychotherapy, 34-41, https://doi.org/10.26565/2410-1249-2018-9-04. Ukrainian)

Kharchenko, A. O. (2020). Complex of Suggestions on Improving the Psychological Correction and Diagnostics of Traumatic Emotional Experience Among Military Servants with Post-Stress Psychological Dysaptation. Psychological Counseling and Psychotherapy, 13, 62-67, https://doi.org/10.26565/2410-1249-2020-13-07.

Mozghovyi V.I. (2017). Теоретичний огляд психосемантичних досліджень військовослужбовців [Theoretical review of psychosemantic research of servicemen.]. Psykholohichne konsultuvannia $i$ psykhoterapiia, seriia Medychna psykholohiia: teoretychni i praktychni pytanian, 1(8), 31-42. (in Ukrainian)

Ozerianskyi, A. А. (2013). Особливості дезаптаційного синдрому у війковослужбовців національних континентів [Features of the dissipation syndrome in servicemen of national continents]. Pravnychyi visnyk Universytetu KROK, 16, 275-284. (in Ukrainian)

Mozghovyi, V.I. (2017) Дослідження поняття психологічного супроводу військовослужбовців на різних етапах службової діяльності [Research of the concept of psychological support of servicemen at different stages of service activity.]. Visnyk Kharkivskoho universytetu imeni $V$. N. Karazina, seriia Psykholohiia, 63, 58-63. (in Ukrainian)

Shnejder, L. B. (2007). Lichnostnaya, gendernaya i professional 'naya identichnost': teoriya i metody' diagnostiki. (in Russian)

\section{ДОСЛІДЖЕННЯ ПОКАЗНИКІВ НЕРВОВО-ПСИХІЧНОЇ СТІЙКОСТІ ТА СОЦІАЛЬНОЇ ЗРІЛОСТІ У ВІЙСБКОВОСЛУЖБОВЦІВ СТРОКОВОЇ СЛУЖБИ ПІД ЧАС ПСИХОЛОГІЧНОГО СУПРОВОДУ}

В. І. Мозговий

кандидат психологічних наук, доцент кафедри психології

Київського національного торгово-економічного університету

Стаття присвячена теоретично-емпіричному дослідженню, важливих особистісних характеристик військовослужбовців: нервово-психічної стійкості та соціально-психологічної зрілості, які є фокусом психологічного впливу з боку психолога військової частини (підрозділу) на всіх основних етапах військової діяльності від призову до звільнення в запас. В статті емпірично досліджено систему зв'язків між показниками нервово-психічної стійкості, соціально-психологічної зрілості та соціальних відносин у військовослужбовців строкової служби на етапах адаптації та виконання завдань за призначенням. Проведено кореляційний аналіз, за Пірсоном, з показниками нервово-психічної стійкості, соціальної зрілості та якістю взаємин з найближчим соціальним оточенням. У результаті аналізу отриманих даних встановлено, що соціальна зрілість безпосередньо пов'язана з якістю соціальних взаємин у військовослужбовця, як в родині, так і у військовому колективі та має тенденцію до зростання під час проходження строковиками військової служби. Рівень стабільності нервово-психічної стійкості, пов'язаний з зростанням соціальної зрілості через розвиток рефлексивної складової. У військовослужбовців, що виконують завдання за призначенням спостерігається позитивна динаміка підвищення рівню соціальної зрілості за рахунок рефлексивної та моральної складової, що вказує на їх особистісне і професійне зростання завдяки організованому психологічному супроводу. Виявлено статистично значущі, для військовослужбовців строкової служби, зв'язки між моральною зрілістю та відносинами зі співслужбовцями та командирами, що є важливою специфічною ознакою соціальнопсихологічного особистісного зростання військовослужбовців, що перебувають на етапі виконання завдань за призначенням. Визначено завдання та очікуваний результат психологічного супроводу на етапах адаптації та виконання завдань за призначенням. Зазначено основні вектори психологічного впливу з боку психолога військової частини. щодо підвищення рівню нервово-психічної стійкості та соціально-психологічної зрілості у військовослужбовців.

Ключові слова: психологічний супровід, етапи військової діяльності, військовослужбовець, психологічне забезпечення, нервово-психічна стійкість, соціально-психологічна зрілість. 